\title{
Importanța familiei în construirea relațiilor cu sinele și cu ceilalți
}

\author{
Camelia Augusta ROȘU*
}

\begin{abstract}
The importance of family in building relationships with oneself and with others. The article provides a psychological perspective on the family, on building relationships within the family, analyzing two important concepts from this point of view: attachment and parenting. From a relational point of view, the family represents the "safe base", to which the child can return at any time when he needs safety, protection, affection. Attachment is the bond that is formed between the child and the mother / caregiver in the first years of life and is the prototype of the relationships that the child will build in the future. The attachment relationship puts its fingeprint on the child's development from a physical, cognitive and psychosocial point of view. Parenting is the ability of parents to be responsible for building the child's personality in the first years of life, to provide education, protection, affection, awareness of the parental role and of the importance of parent-child relationship in the first years of life. Educational styles, parental attitudes and parental competence are factors that decisively condition the construction of the parent-child relationship and the child's development in the first years of life.
\end{abstract}

Keywords: family, attachment, parenting, relationship, educational styles.

\section{Introducere}

Familia a fost şi este obiectul de studiu pentru multiple discipline, de la sociologie, la pedagogie, psihologie, filozofie,

* Lect. univ. dr., Departamentul pentru Pregătirea Personalului Didactic, Universitatea „1 Decembrie 1918” din Alba Iulia. 
teologie, etc. Fiecare dintre aceste discipline, prin instrumente specifice, a ilustrat o parte din ceea ce înseamnă familia. Prezentul articol se oprește asupra unei perspective psihologice a familiei, încercând să sublinieze importanța familiei în modul în care copilul învaţă să își construiască relaţiile cu cei din jur, dar și cu propria persoană. Familia este baza sigură, la care copilul face referință și la care se poate întoarce oricând, este locul în care copilul se simte în siguranță, se simte protejat și iubit.

Articolul este construit în jurul a două teme importante: ataşamentul şi parentalitatea. Relaţia de ataşament este acea legătură care se formează între copil și mamă/îngrijitor în primii ani de viață, legătură care condiționează formarea relațiilor pe care copilul le va avea în viitor. Atitudinea, comportamentul părinților (sau a îngrijitorilor) îl ajută pe copil să își formeze o concepție despre sine şi despre lume, să construiască o harta interioară, care îl orientează în viața.

„Atașamentul este astfel considerat o legătură intrafamilială, deci parte a sistemului familial. Familia este un sistem de relații de înrudire cu reglementări diferite în funcție de cultura respectivă. Nucleul său principal este constituit din legături afective stabilite între membrii săi"l.

Stilurile parentale au o importanță decisivă în formarea personalităţii copiilor, atitudinea părintelui condiţionând dezvoltarea psihică, cognitivă și psihosocială a copilului. Construirea propriei imagini depinde de modalităţile relaţionale părinte-copil care pot fi adecvate sau neadecvate, de atitudinea pozitivă sau negativă a părinților în relație, de prezența sau absența sentimentului de protecție și de siguranță. Calitatea relațiilor părinte-copil este legată de bunăstarea fizică și psihică a copilului.

Familia și educația sunt doi termeni care se interconectează. Familia are o clară funcție educativă, formativă, în familie se pun bazele educației copilului, se învață primele norme și valori, se formează conduita morală, se identifică și se gestionează emoțiile,

${ }^{1}$ Leticia Solis-Ponton, Parentalitatea. Provocare pentru mileniul trei, București, Edit. Trei, 2017, pp. 207-208. 
se formează comportamente. Educația se realizează în primul rând în familie, în primul nucleu social, care pune bazele societății, prin educație se construiește familia. Familia este ambientul în care copilul regăsește afecțiunea de care are nevoie pentru a-și dezvolta personalitatea în mod echilibrat, unde i se oferă protecție faţă de orice pericol, este mediul care educă, care modelează.

Relația părinte copil stă la baza dezvoltării persoanei în primele etape de dezvoltare, dar și ulterior. Copilul este deschis relației încă din momentul nașterii, considerând faptul că supraviețuirea sa fizică și psihologică depinde de grija și atenția părintelui.

„Atmosfera din familie este, pentru copil, soarele, apa, căldura și solul pentru o plantă. Un copil nu are nevoie numai de mâncare pentru trup, ci și de hrană pentru suflet, de aceea, armonia căminului, dragostea și înțelegerea dintre părinți, prezența și atenția lor, atitudinea lor dreaptă şi nepărtinitoare față de copii, sentimentul de unitate a familiei, senzația de siguranță și ocrotire pe care o trăiește copilul în sânul familie contează mai mult decât toate jucăriile și bunătățile din lume, decât cele mai exotice vacanțe și cele mai frumoase hăinuțe",2.

\section{Ataşamentul}

Ataşamentul este legătura emoțională pe care copilul o dezvoltă cu mama sau persoana de referință. „Este un proces activ de adaptare, bazat pe dezvoltarea de strategii pentru satisfacerea nevoilor de securitate, formulate în raport $\mathrm{cu}$ caracteristicile mediului și cu capacitatea sporită de a elabora gândirea și de a organiza comportamentul"'.

Teoria atașamentului, creată de John Bowlby, reprezintă o modalitate de a conceptualiza şi explica legătura mamă-copil, subliniind în acest sens rolul central al relaţiilor în dezvoltarea

${ }^{2}$ Irina PetreA, Și tu poți fi supernanny, București, Edit. Trei, 2011, p. 175.

${ }^{3}$ Lucia CARLI, Dalla diade alla famiglia. I legami di attaccamento nella rete familiare, Milano, Raffaello Cortina, 1999, p. XI. 
ființei umane. Condiţia fundamentală pentru construirea relației de ataşament este continuitatea și stabilitatea relației pe care copilul o are cu mama. Teoria ataşamentului susține, de asemenea, că relația de ataşament pe care copilul o construiește cu mama va constitui prototipul tuturor următoarelor relații pe care copilul le va avea în viitor. În trecut teoria atașamentului era considerată doar în raport cu relația mamă-copil, astăzi însă această teorie este considerată în raport cu relația adult-copil.

Copilul, în conformitate cu teoria atașamentului, se naște cu o predispoziție genetică de a căuta și de a menține apropierea de o persoană de referință, care în general este mama. Bowlby, oferind o explicație evoluționistă, afirmă că relațiile de atașament au o funcție protectoare. Comportamentele de atașament se manifestă cu o intensitate mai mare în situații de pericol. Aceste relaţii există într-un mod organizat la sfârșitul primului an de viață. Sistemul comportamentelor de ataşament este similar unui sistem fiziologic organizat în mod homeostatic. Bowlby afirmă că, în același mod în care un ,boiler” trebuie să mențină temperatura apei la un nivel constant, copilul trebuie să mențină relația cu persoana de referință, în anumite limite ale distanței și accesibilității. Aceste limite sunt menținute grație metodelor comportamentale și nu prin mijloace fiziologice ${ }^{4}$.

Legătura copilului cu mama este ,,produsul activității diferitelor sisteme comportamentale care au rezultatul previzibil al menținerii apropierii copilului de mamă" 5 . Prin urmare, creșterea copilului are loc într-o dialectică continuă între apartenență și separare, între împingerea şi menținerea apropierii de persoana de referință.

Sistemul de comportamente de atașament responsabil și garant al siguranței copiilor în mediul înconjurător are aceeași importanță ca și sistemele care reglează consumul de alimente și activitatea de reproducere. Acest sistem important îl conduce pe copil în controlul accesibilității persoanelor de referință și în căutarea acestor persoane ca siguranță în caz de pericol ${ }^{6}$.

${ }^{4}$ Adriana Lis, et. al, Manuale di psicologia dinamica, Bologna, Il Mulino, 1999.

5 Ibidem, p. 356.

6 John BowlBy, Attachment and loss: Vol. 1. Attachment, New York, Basic Books, 1982. 
Legătura de atașament în copilărie se manifestă ca o succesiune de relații diadice care sunt asimetrice în sensul că, copilul primește îngrijire, dar nu o oferă. Ulterior, începând cu adolescența, legăturile de atașament devin simetrice, se înmulțesc și se influențează reciproc. Atașamentul, dincolo de funcția protectoare permite, de asemenea, o calitate reciprocă a interacțiunii cu figura de ataşament. Astfel, se poate deduce că, calitatea ataşamentului influențează calitatea relației.

Teoria atașamentului folosește un limbaj direct, accesibil și inteligibil chiar și pentru nespecialiști, iar acest lucru se datorează faptului că principalul său obiect de cercetare, şi anume ataşamentul, este o temă care ne privește pe toți și care influențează întreaga noastră viață, sub forme și intensități diferite.

Termenul de „bază sigură” se datorează faptului că Mary Ainsworth a colaborat cu Bowlby și a creat sistemul de codificare pentru a clasifica cele trei modele de relații de bază la copiii de vârstă preșcolară reuniți cu părinții după o lungă perioadă petrecută într-un spital.

În mod metaforic, Holmes compară „,bază sigură” cu un port sigur, spunând că ,putem înfrunta mări periculoase dacă suntem convinşi că avem un refugiu sigur”. Pe baza studiilor realizate de Bowlby și Ainsworth, Holmes distinge patru faze ale ontogenezei sistemului de atașament:

- 0 - 6 săptămâni: faza premergătoare ataşamentului sau preataşamentul;

- 6 săptămâni - 6 luni: orientare și model de recunoaștere;

- 6 luni - 3 ani: ataşament „,consolidat”;

- începând cu trei ani: formarea unei relaţii reciproce (Holmes 1993).

Ainsworth împreună cu Bolwby și alți cercetători au studiat ceea ce înseamnă carența maternă, deoarece are efecte diferite asupra proceselor de dezvoltare ale copiilor și mai ales asupra copiilor instituționalizați. Principalele lipsuri sunt:

1) carența care apare atunci când un bebeluș sau copil, care trăiește într-un spital sau instituție, nu găsește o persoană care să o 
poate înlocui în mod adecvat pe mamă și, prin urmare, nu primește îngrijirea maternă necesară;

2) carența care apare atunci când un un bebeluș sau un copil care trăiește cu mama (sau o persoană care o înlocuiește permanent) nu primește îngrijire satisfăcătoare și nu are ocazia să interacționeze suficient cu ea;

3) carenţa care apare atunci când copilul nu este în măsură să interacționeze cu figura maternă sau cu cea care o înlocuiește, chiar dacă condițiile de îngrijire sunt excelente ${ }^{7}$.

Prin urmare, carența implică lipsa interacțiunii sau o slabă interacțiune între copil și persoana care se ocupă de el. Aceasta implică o discontinuitate a relației sau deformarea interacțiunilor. Cercetătorii au examinat carența ca rezultat al separării de mama și rezultatul mai evident al integrării într-o instituție. Trebuie subliniat că efectele carenței materne pot fi cantitative (în sensul separării sau lipsei figurii materne), dar și calitative (în sensul incompetenței figurii materne). De asemenea, trebuie subliniat faptul că efectele a ceea ce înseamnă carența maternă depind de o serie de alte variabile, cum ar fi mediul, individualitatea fiecărei persoane etc.

Ainsworth a studiat de-a lungul mai multor ani interacțiunile dintre mame și copiii lor și a identificat trei tipuri principale de atașament:

Stilul de atașament securizant (sau sigur) este un stil de atașament în care copilul se simte susținut, protejat de către figura de ataşament, atunci când este în pericol, se simte liber să poată explora lumea, se simte în siguranță și are încredere în el şi în ceilalți.

Stilul insecurizant (sau nesigur) evitant este un stil de ataşament în care copilul se simte respins de figura de ataşament, nu se simte iubit, are încredere doar în el, nu are încredere în ceilalți.

Stilul insecurizant (sau nesigur) anxios ambivalent este un stil de ataşament în care copilul este anxios, explorează lumea în mod ezitant, nu are încredere în figura de atașament, care este

${ }^{7}$ Mary D. Ainsworth, La carenza delle cure materne, Roma, Armando, 1979. 
disponibilă doar uneori, nu are încredere în propria persoană, dar are încredere în ceilalți ${ }^{8}$.

Pe lângă cele trei stiluri de atașament propuse de Ainsworth, s-a identificat și un al patrulea stil de ataşament - stilul dezorganizat. Copilul cu acest stil de atașament nu găsește sprijin în figura de atașament, ci mai degrabă simte nesiguranța și frică în raport cu aceasta ${ }^{9}$.

\section{Parentalitatea}

Plecând de la importanța relației de atașament care se construiește în primii ani de viață între copil și figurile semnificative (figuri care contribuie la creșterea și educația copilului), este necesar să dăm spațiu și parentalității.

Foarte mulți dintre părinții de astăzi consideră că parentalitatea ține de activitățile extrașcolare pe care le organizează pentru copil, antrenamentele de fotbal, baletul, orele suplimentare de limbă engleză, etc., și nu se bucură de timpul efectiv petrecut cu copilul. Copiii însă au nevoie de acele relații apropiate, au nevoie, aşa cum am vazut, de legătura de ataşament în care se simt în siguranță, au nevoie de părinți.

Parentalitatea este capacitatea părinților, mamă și tată, de a fi prezenți și activi în viața copilului, de a oferi educație, protecție, afecțiune. Parentalitatea nu poate fi redusă la simpla postură de a da naștere unui copil, ci presupune conștientizarea rolului de părinte, îndeplinirea misiunii de părinte responsabil de construirea personalității copilului în primii ani de viață.

Copilul, în primii ani de viață, se bazează pe interacțiunile cu adulții din jur, cu părinții, gândurile, emoțiile, acțiunile copilului se formează în relație cu adulții, sunt direcționate către adulți. Părinții influențează dezvoltarea copiilor prin propriul mod de relaționare

${ }^{8}$ Mary D. Ainsworth, Modelli di attaccamento e sviluppo della personalità, Milano, Raffaello Cortina, 2006.

9 Mary MaIN \& Judith Solomon, Procedures for identifying infants as disorganized/disoriented during the Ainsworth Strange Situation, Chicago, University of Chicago Press, 1990. 
cu aceștia. În acest sens părinții pot fi influențați în relațiile pe care le construiesc $\mathrm{cu}$ copiii lor de experiențele pe care le-au avut în trecut (propria copilărie) sau de proiecțiile pe care le au (propriile dorințe proiectate pe copii).

Relațiile pe care părinții le construiesc cu copiii contribuie la formarea stimei de sine și influențează performanța școlară. ,,.. copiii care primesc sprijin și căldură din partea familiei se caracterizează prin încredere, stimă de sine crescută, iar cei care sunt respinşi ori au părinți autoritari tind să se simtă inferiori, nu dispun de capacitatea de a oferi și de a primi afecțiunea altora, sunt triști, se simt vinovați și preferă să stea singuri" "10.

Construirea sinelui se realizează în mai multe dimensiuni ${ }^{11}$ :

- domeniul biologic - sinele în relație cu corpul (relația cu propriul corp, care trăiește și respiră);

- domeniul intrapsihic - sinele în relaţie cu sinele (dialogurile între diferitele părți ale sinelui, lumea interioară a persoanei);

- domeniul inter-personal - sinele în relație cu ceilalți (relațiile interpersonale, legărturile cu cei din jur);

- domeniul intercultural și contextual: sinele în relaţie cu contextul (experiențele sinelui integrate în context);

- domeniul ecologic - sinele în relaţie cu mediul înconjurător și natura (relația dintre oameni și natură, modul în care oamenii pot influența natura);

- domeniul transcedental: sinele în relație cu lumea transpersonală și spirituală (omul caută sensul existenței sale, își dezvoltă sinele spiritual).

Dimensiunea intrapsihică şi cea interpersonală sunt două dimensiuni foarte importante în formarea sinelui. Relația părinte copil din primii ani de viață influențează construirea acestor două dimensiuni, copilul construind prin intermediul lor lumea interioară - relația cu sinele, precum și lumea externă - relația cu persoanele din jur.

${ }^{10}$ Florinda Golu, Manual de psihologia dezvoltării. O abordare psihodinamica, Iaşi, Edit. Polirom, 2015, p. 141.

${ }^{11}$ Ken EvANS \& Maria GILBERT, Introducere în psihoterapia integrativă. Un model relaţional integrativ al psihoterapiei, Bucureşti, Edit. Liber Mundi, 2014. 
Competența parentală trebuie să includă și dimensiunea jocului, acel limbaj care poate deveni comun între părinte și copil. „Parentalitatea prin joc oferă ajutor pentru cele mai dificile aspecte ale creșterii copiiilor: crizele de nervi ale copiilor de doi-trei ani, mușcatul la preșcolari, anxietatea copiilor de clasa a treia, comportamentul scăpat de sub control al preadolescenților... bătăliile pentru îmbrăcat și pregătit dimineața" 12 .

Jocul este o parte foarte importantă a dezvoltării copilului. Prin intermediul jocului copiii se pot exprima emoțional, pot să arate părinților ceea ce simt, ceea ce nu vor sau nu știu să exprime la nivel verbal (mai ales în cazul copiilor mici).

Atitudinile parentale trebuie să răspundă nevoilor pe care copilul le are. Atitudinile parentale eficiente din punct de vedere educațional sunt cele care implică acceptarea copilului și încurajarea autonomiei. Golu (2015) specifică importanţa construirii atmosferei psihologice din familie prin combinarea dimensiunilor de acceptanță (iubire)-autonomie; acceptanță-control; respingere-autonomie; respingere-control. Părinții trebuie să promoveze acceptanța și să o îmbine cu un control flexibil, să ofere copiilor stabilitate emoțională, optimism, cooperare și deschidere, asertivitate, inițiativă și socializare.

În literatura de specialitate ${ }^{13}$ găsim descrierea a trei tipuri de stiluri educaționale: democratic, laisser-faire și autocratic. Aceste stiluri sunt folosite pentru a analiza modalitatea de relaționare a cadrului didactic, sau a părintelui față de copil.

Stilul educaţional democratic este un stil ideal caracterizat de cooperarea dintre adult și copil, de parteneriatul dintre aceştia, de comunicare, de implicarea copilului în relație. Stilul educațional laisser-faire sau permisiv se caracterizează prin lipsa de cooperare dintre elev și profesor, comunicare disimetrică, dominarea relaţiei adult-copil de către copil. Stilul educațional autocratic sau autoritar este un stil în care relația este dominată de adult, lipsește comunicarea și cooperarea, copilul este redus la stadiul de obiect și

${ }^{12}$ Lawrence J. CoHEn, Rețete de jocuri. De ce și cum să te joci cu copilul tău, București, Edit. Trei, 2012, p. 32.

${ }^{13}$ Cosntantin Cucoș, Pedagogie, Iași, Edit. Polirom, 2006. 
este necesară prezența permanentă a adultului ${ }^{14}$. Stilul de tip democratic este stilul educațional ideal, care asigură o dezvoltare armonioasă a copilului.

O altă descriere a modelelor relaționale/stilurilor educaționale ne prezintă mai multe tipare parentale: modelul părinţilor autoritari - în care predomină disciplina, rigiditatea, pedeapsa; modelul părinților indulgenți - caracterizat de toleranța și lipsa autorității; modelul părinților protectori/hiperprotectori presupune atenție și îngrijorare exagerată din partea părintelui; modelul părinților inconsecvenți - caracterizat de inconsecvența adultului; modelul părinților indiferenți - în care întâlnim neglijare și indiferență; modelul părinților agresivi - dominat de agresivitate şi modelul părinților eficienți - în care există empatie, respect, reguli dar și libertate.

„Mediul familial constituie cadrul în care se petrece socializarea primară a copilului, contextul în care acesta are experiența contactului cu anumite norme, valori, modele pe care va încerca să le înțeleagă, să și le apropie și să le interiorizeze" ${ }^{15}$.

E important să conștientizăm că într-o familie există de obicei doi părinți, și că ambii trebuie să se implice în mod activ în creșterea și educaţia copiilor. Fiecare dintre părinţi are un rol specific, mama are rolul ei, iar tatăl are rolul lui, sunt două modele diferite de care copiii au nevoie. Părinţii trebuie să lucreze în echipă, să se susțină reciproc, să fie coerenți în procesul educațional al copiilor.

Societatea de astăzi tinde să nege importanța prezenței tatălui în creșterea și educaţia copiilor, și în contextul numeroaselor divorțuri. „Valorile sociale trebuie transmise de la tata la fiu, asemenea torței olimpice. De cele mai multe ori, mama singură nu e suficientă" ${ }^{\prime 6}$.,...copilul simte nevoia să știe că are un tată, chiar dacă mama este celibatară; este o nevoie absolută" ${ }^{17}$. Dacă mama

\footnotetext{
${ }^{14}$ Ibidem, p. 331-332.

${ }^{15}$ Florinda Golu, Manual de psihologia dezvoltării..., p. 92.

${ }^{16}$ Michael Gurian, Miracolul băieților. Ce pot face părinții și educatorii pentru a transforma băieții în bărbați de excepție, București, Edit. Trei, 2017, p. 186-187.

${ }^{17}$ Françoise Dolto, Ce să le spunem copiilor, București, Edit. Trei, 2005, p. 72.
} 
reprezintă partea afectivă în educația copiilor, tatăl reprezintă partea de disciplină, de morală, amândoi sunt părțile unui întreg parentalitatea.

Copilul își dezvoltă în mod echilibrat personalitatea în cadrul familiei dacă se simte iubit şi apreciat, dacă îi sunt satisfăcute nevoile în mod adecvat, dar și dacă părinții știu să folosească limite - acele repere prin care copilul învață să gestioneze emoțiile, să tolereze frustrarea, să distingă lumea externă și de cea internă. Limitele sunt necesare, însă ele nu trebuie impuse în mod autoritar și rigid, ci ele trebuie să existe ca reper al siguranței, ca bază pentru asimilarea normelor și învăţarea regulilor. Pe măsură ce copilul crește limitele se schimbă, pentru a se adapta noilor nevoi care apar în dezvoltarea copilului.

Părinții au o sensibilitate parentală prin care reuşesc să răspundă nevoilor copiilor în manieră adecvată. Există patru funcții ale educației părinților: funcția securizantă - copilul se simte în siguranță în relația cu părinții; funcția stimulantă - părinții stimulează copilul prin ceea ce fac, prin ceea ce spun și prin ceea ce simt; funcția de socializare - relațiile cu cei din jur, relații inițiate de părinți, îl ajută pe copil să se adapteze; funcția de transmitere a valorilor - valorile se transmit în familie, de la o generaţie la alta ${ }^{18}$.

\section{Concluzii}

În cadrul articolului s-au evidențiat legături clare între familie și relaţie, familie şi educaţie, familie şi dezvoltare, familie şi personalitate, etc. Toate aceste legături ne demonstrează importanța familiei pentru o multitudine de dimensiuni din viața persoanei. Familia este un punct de referință fundamental pentru viitorul copiilor, ceea ce este copilul astăzi, ceea ce va fi mâine ca şi adult depinde de contextul familial în care crește.

Primii ani din viaţa unui copil sunt foarte importanţi pentru a pune bazele unui atașament sigur și pentru a stimula multe dintre aspectele dezvoltării fizice, cognitive și psihosociale. Familia este

${ }^{18}$ Leticia Solis-Ponton, Parentalitatea ..., 2017. 
baza sigură de care copilul are nevoie pentru a se simţi protejat și în siguranță, iar legăturile de atașament construite în cadrul familiei conduc la construirea unor relații echilibrate și armonioase și în contextele ulterioare în care intră copilul - grădiniță, școală, grup de prieteni, comunitate, societate.

$\mathrm{Nu}$ toate relațiile pe care copilul le construiește cu cei din jur în primii ani de viață, deși semnificative, pot fi considerate relații de atașament. Pentru ca o relație să fie considerată o relație de atașament, trebuie să fie prezente câteva condiții de bază: căutarea apropierii între persoana care caută atașament și cea care o oferă, prezența reacțiilor de protest în fața separării și dezvoltarea bazei sigure - atmosfera de securitate și încredere care se stabilește între persoană și figura de ataşament.

Copilul care își formează un atașament de tip sigur în relația cu mama/îngrijitorul va fi o persoană care va avea încredere în ea însăşi și în cei din jur, va construi relații bazate pe respect şi încredere, se va simți în siguranța în cadrul relațiilor și va oferi protecție celor pe care îi va iubi, va fi empatic, dar şi autonom, va gestiona cu ușurință situațiile dificile, care vor apărea pe parcursul vieții

Relația părinte-copil este o relaţie de interdependență, o relație de reciprocitate. Copilul are nevoie de părinte pentru creștere și educație, iar părintele are nevoie de copil pentru a-și îndeplini misiunea de părinte.

Parentalitatea implică abilitatea de a avea grijă de acea mică ființă în devenire, atât din punct de vedere fizic, cât și emoțional, de a răspunde în mod adecvat nevoilor pe care copilul le are în diferite momente evolutive, parentalitatea implică arta de a fi părinte.

A fi părinte poate fi o provocare, în a răspunde în mod adecvat nevoilor copilului, în a înțelege specificul diferitelor faze evolutive, în a avea stilul educațional adecvat, în a se adapta rolului de părinte. Dar în această provocare părintele nu trebuie să fie perfect, ci trebuie să fie „suficient de bun”19.

19 Donald W. WinnicotT, Copilul, familia și lumea exterioară. București, Edit. Trei, 2013. 
Părintele eficient, părintele cu un stil educaţional democratic este părintele care a învățat arta de a fi părinte, care și-a construit competența parentală, părintele care a conștientizat importanța primilor ani de viața în formarea personalității copilului.

Pandemia de coronavirus a condus spre schimbări socioculturale profunde, şi aceste schimbări se reflectă şi la nivelul familiei. Efectele acestei crize mondiale se resimt în relația părintecopil, prin afectarea funcției de socializare a familiei, a modalităților de comunicare, a realizării procesului de educaţie. În acest context provocator, de criză și schimbări rapide, de incertitudine și nesiguranță, cred că e important să regândim misiunea familiei, să investim în acest nucleu al societății, să reconstruim relația părintecopil, pentru că avem oportunitatea de a avea timp, de a avea spațiu pentru familie, pentru educaţia în familie.

Cel mai mare dar pe care copilul îl poate primi la naștere este o familie în care să fie dorit, ascultat, iubit, protejat, o familie care îi dă aripi să zboare, o familie care să reprezinte baza sigură, la care se poate întoarce atunci când are nevoie. Familia este, în mod plastic, leagănul relațiilor pe care copilul le construiește cu ceilalți, dar şi cu propria persoană.

0380

\section{Bibliografie}

1. Ainsworth, Mary D., La carenza delle cure materne, Roma, Armando, 1979.

2. Ainsworth, Mary D., Modelli di attaccamento e sviluppo della personalità, Milano, Raffaello Cortina, 2006.

3. Bowlby, John, Attachment and loss: Vol. 1. Attachment, New York, Basic Books, 1982.

4. BowlBy, John, Crearea şi ruperea legăturilor afective, Bucureşti, Edit. Trei, 2016.

5. BowlBy, John, The Making and Breaking of Affectional Bonds, London, Tavistock, 1979.

6. Brazelton, T. Berry \& CRAMER, Bertrand G., The earliest relationship: Parents, infants, and the drama of early attachment, Boston, Da Capo Press, 1990. 
7. CARLI, Lucia, Dalla diade alla famiglia. I legami di attaccamento nella rete familiare, Milano, Raffaello Cortina, 1999.

8. CoHEN, Lawrence J., Rețete de jocuri. De ce și cum să te joci cu copilul tău, București, Edit. Trei, 2012.

9. Crețu, Tinca, Psihologia vârstelor, Iași, Edit. Polirom, 2016.

10. CuCoș, Constantin, Pedagogie, Iași, Edit. Polirom, 2006.

11. Dolto, Françoise, Ce să le spunem copiilor, București, Edit. Trei, 2005.

12. EVANS, Ken \& GILBERT, Maria, Introducere in psihoterapia integrativă. Un model relational integrativ al psihoterapiei, Bucureşti, Edit. Liber Mundi, 2014.

13. Golu, Florinda, Manual de psihologia dezvoltarii. $O$ abordare psihodinamica, Iași, Edit. Polirom, 2015.

14. Gurian, Michael, Miracolul băieților. Ce pot face părinții și educatorii pentru a transforma băieții în bărbați de excepție, București, Edit. Trei, 2017.

15. HOLMES, Jeremy, The search for the secure base: Attachment theory and psychotherapy, New York, Brunner-Routledge, 2001.

16. LIS, Adriana et al, Manuale di psicologia dinamica, Bologna, Il Mulino, 1999.

17. MAIN, Mary \& Solomon, Judith, Procedures for identifying infants as disorganized/disoriented during the Ainsworth Strange Situation, Chicago, University of Chicago Press, 1990.

18. Papalia, Diane E., WendKos, Sally Olds \& Feldman, Ruth Duskin, Dezvoltarea umană, București, Edit. Trei, 2009.

19. PetreA, Irina, Și tu poți fi supernanny, București, Edit. Trei, 2011.

20. SHAPIRO, Lawrence E., Limbajul secret al copiilor. Cum să-ți ințelegi mai bine copilul, București, Edit. Trei, 2011.

21. Solis-PonTON, Leticia, Parentalitatea. Provocare pentru mileniul trei, București, Edit. Trei, 2017.

22. VERZA, Emil \& VERZA, Florin Emil, Psihologia copilului, București, Edit. Trei, 2007.

23. WinNicotT, Donald W., Copilul, familia și lumea exterioară. București, Edit. Trei, 2013. 